\title{
PENGARUH ARUS KAS OPERASI DAN PERTUMBUHAN PENJUALAN TERHADAP HARGA SAHAM PADA PERUSAHAAN INDEKS LQ45 YANG TERDAFTAR DI BURSA EFEK INDONESIA TAHUN (2012-2016)
}

\author{
Natalia Debora Kumayas ${ }^{1}$, Sifrid Pangemanan ${ }^{2}$, Stanly Alexander ${ }^{3}$ \\ ${ }^{1,2,3}$ Jurusan Akuntansi, Fakultas Ekonomi dan Bisnis, Universitas Sam Ratulangi, Jl. Kampus Bahu, Manado, \\ 95115, Indonesia
}

E-mail : kumayasdebora@yahoo.com

\begin{abstract}
This research aims to examine the influence the effect of revenue and growth of the company on stock prices on LQ45 listed on Indonesia Stock Exchange 2012-2016. The population used in this study is the LQ45 company index listed on the Indonesia Stock Exchange 2012-2016. Method of sampling by purposive sampling according to predetermined criteria. The number of samples collected by 6 companies. Research data is secondary data obtained from Indonesia stock exchange (BEI) in 2012-2016. The collected data were analyzed using the first data analysis done by classical testing before hypothesis testing. Hypothesis testing in this research is multiple linear regression analysis with $t$ test, $f$ test, and coefficient of determination. The results of this study indicate that the variable cash flow positive and not significant to stock prices. This shows that the operation does not affect the high stock prices. While the growth of positive and significant sales to stock prices. This suggests that sales growth is driving high stock prices low.
\end{abstract}

keywords: Operating cash flow, sales growth, stock price

\section{PENDAHULUAN}

Kegiatan menanamkan modal termasuk suatu bagian untuk menempatkan dana pada satu asset atau lebih, selama periode tertentu dengan harapan dapat memperoleh penghasilan dan peningkatan nilai investasi. Pasar modal adalah tempat bertemunya pihak yang mempunyai kelebihan dana (investor) dengan pihak yang kekurangan dana (perusahaan). Dalam pasar modal, investor memainkan peranan sentralnya yaitu dengan membeli dan menjual saham atau surat - surat berharga (efek) lainnya melalui perusahaan - perusahaan efek yang terdaftar resmi di bursa efek. Saham sendiri merupakan bentuk modal penyertaan atau bukti posisi kepemilikan dalam suatu entitas. Harga saham merupakan indikator keberhasilan pengelolaan perusahaan dimana kekuatan pasar ditunjukkan dengan transaksi perdagangan saham perusahaan di pasar modal. Reaksi harga saham dapat ditunjukkan dengan adanya perubahan harga dari sekuritas yang bersangkutan (Faris Fashihul Lisan: 2011). Hery (2017 : 324) Arus kas yang paling utama dari perusahaan adalah terkait dengan aktivitas operasi, Aktivitas operasi meliputi transaksi-transaksi yang tergolong sebagai penentu besarnya laba/rugi bersih, seluruh akun pendapatan dan beban yang merupakan komponen penentu laba bersih menggambarkan (identik dengan) aktivitas operasi perusahaan. Para Investor menggunakan informasi arus kas sebagai pengukuran kinerja yang mampu menggambarkan kondisi ekonomis serta mampu menyediakan dasar proyeksi arus kas di masa yang akan datang yang cenderung diukur melalui harga atau harga saham. Peningkatan penjualan juga merupakan petunjuk permintaan dan daya saing perusahaan dalam suatu industri. Subramanyam (2014 : 487) Pertumbuhan penjualan adalah analisis tren dalam penjualan berdasarkan segmen berguna dalam menilai profitabilitas, pertumbuhan penjualan sering merupakan hasil dari satu atau lebih faktor, termasuk perubahan harga, perubahan volume, akuisisi/divestasi, dan perubahan nilai tukar. Laju pertumbuhan suatu 
perusahaan akan mempengaruhi kemampuan mempertahankan keuntungan dalam mendanai kesempatann-kesempatan pada masa yang akan datang. Akibatnya banyak investor yang tertarik untuk menanamkan sahamnya di perusahaan tersebut, sehingga harga saham perusahaan meningkat. LQ45 adalah indeks pasar saham di Bursa Efek Indonesia (BEI). Perusahaan LQ45 merupakan perusahaan yang memiliki harga-harga saham unggulan dan merupakan bagian perusahaan yang sahamnya paling diminati oleh para investor. Investor jangka panjang biasanya membidik saham di LQ45 merupakan suatu kehormatan bagi sebuah perusahaan karena itu berarti pelaku pasar modal sudah mengakui dan percaya bahwa tingkat likuiditas dan kapitalisasi pasar dari perusahaan ini baik.

\section{TINJAUAN PUSTAKA}

\subsection{Akuntansi Keuangan}

Akuntansi keuangan memiliki hubungan dengan masalah pencatatan transaksi dalam suatu perusahaan atau suatu unit ekonomi yang lain dan mengenai penyusunan berbagai laporan periodik dari catatan-catatan tersebut. Hasil akhir dari proses akuntansi keuangan adalah laporan keuangan yang dapat memberikan informasi bagi pengguna eksternal organisasi guna pengambilan keputusan.

\subsection{Laporan Keuangan}

Ikatan Akuntan Indonesia (2015:3) laporan keuangan adalah suatu penyajian terstruktur dari posisi keuangan dan kinerja keuangan suatu entitas, yang menunjukkan hasil pertanggungjawaban manajemen atas penggunaan sumber daya yang dipercayakan kepada mereka.

\subsection{Pasar Modal}

Pasar modal memiliki peran penting bagi perekonomian suatu negara Di pasar modal terdapat berbagai macam informasi, seperti laporan keuangan, kebijakan manajemen, rumor di pasar modal, prospectus, saran dari broker, dan informasi lainnya. Untuk pengembangan usaha, ekspansi, penambahan modal kerja dan lain-lain dapat menggunakan dana dari pasar modal.

\subsubsection{Saham}

Bodie et al (2014:42) saham merupakan bagian kepemilikan dalam suatu perusahaan yang di mana setiap lembarnya memberi hak satu suara kepada pemiliknya. Bagi pihak yang memiliki saham akan memperoleh beberapa keuntungan sebagai bentuk kewajiban yang harus diterima, yaitu (Fahmi 2012:86) Memperoleh dividen yang akan diberikan pada setiap akhir tahun untuk saham biasa dan setiap kuartal untuk saham istimewa; Memperoleh capital gain, yaitu keuntungan pada saat saham yang dimiliki tersebut di jual kembali pada harga yang lebih mahal; dan Memiliki hak suara bagi pemegang saham jenis common stock (saham biasa).

\subsection{Harga Saham}

Harga saham merupakan faktor yang sangat penting dan harus diperhatikan oleh investor dalam melakukan investasi karena harga saham menunjukkan investasi emiten. Nilai suatu Harga saham di indeks pasar modal terbagi atas tiga bagian, yang termasuk Harga terbesar atau terkecil merupakan harga yang paling besar atau paling kecil yang terjadi pada satu hari bursa. Harga penutupan ditentukan dari harga terakhir yang terjadi pada saat akhir jam bursa.

\subsection{Arus Kas Operasi}

Kieso et al (2011) Arus kas dari aktivitas operasi adalah: Aktivitas operasi melibatkan efek uang tunai dari transaksi yang masuk ke dalam penentuan laba bersih, seperti penerimaan kas dari penjualan barang dan jasa dan pembayaran tunai kepada pemasok dan karyawan untuk mendapatkan pasokan dan untuk membayar biaya. Kemampuan perusahaan dalam memperoleh dana yang cukup untuk dapat melanjutkan usahanya umumnya diukur 
dari sumber kas. Untuk itu, arus kas tersebut pada umumnya berasal dari transaksi dan peristiwa lain yang mempengaruhi penetapan laba atau rugi.

\subsection{Pertumbuhan Penjualan}

Pendapatan utama perusahaan diperoleh dari operasi penjualan, akibat aktivitas penjualan produk maupun jasa tidak dikelola dengan baik secara langsung dapat merugikan perusahaan. Pertumbuhan penjualan Widarjo dan Setiawan (2009) adalah pertumbuhan penjualan (sales growth) mencerminkan kemampuan perusahaan dari waktu ke waktu. Semakin tinggi tingkat pertumbuhan penjualan suatu perusahaan maka perusahaan tersebut berhasil menjalankan strateginya.

\subsection{Penelitian terdahulu}

1. Penelitian yang dilakukan oleh Erlin (2016), menyatakan bahwa arus kas operasi berpengaruh signifikan terhadap harga saham

2. Penelitian yang dilakukan oleh Kurnia (2016), menyatakan bahwa pertumbuhan penjualan berpengaruh signifikan terhadap harga saham

\subsection{Hipotesis}

$\mathrm{H} 1$ = arus kas operasi berpengaruh signifikan terhadap harga saham

$\mathrm{H} 2$ = pertumbuhan penjualan berpengaruh signifikan terhadap harga saham

\section{METODE PENELITIAN}

\subsection{Jenis Penelitian}

Metode yang digunakan penelitian ini yaitu metode penelitian asosiatif, penelitian asosiatif adalah penelitian yang bertujuan untuk mengetahui pengaruh ataupun juga hubungan antara dua variabel atau lebih (Sugiyono 2013:11). Untuk mengetahui Pengaruh Arus Kas Operasi dan Pertumbuhan Penjualan terhadap Harga Saham pada Perusahaan indeks LQ45 yang terdaftar di Bursa Efek Indonesia menggunakan metode asosiatif.

\subsection{Tempat dan Waktu Penelitian}

Penelitian ini dilakukan di beberapa perusahaan indeks LQ45 yang terdaftar pada Bursa Efek Indonesia (BEI). Berdasarkan data yang diperoleh melalui situs BEI di www.idx.ac.id dan di pusat informasi pasar modal yang terletak di Jl. Piere Tendean Komp.Mega Mas Boulevard, Manado.Penelitian ini dilaksanakan pada tahun 2018 dan diperkirakan dilakukan selama dua bulan.

\subsection{Populasi dan Sampel}

Seluruh perusahaan indeks LQ45 yang terdaftar pada Bursa Efek Indonesia merupakan populasi dalam penelitian ini. Metode sampel yang diterapkan adalah metode purposive sampling, yang mana adalah teknik pengambilan sampel sumber data dengan pertimbangan terntentu Perusahaan diseleksi berdasarkan kriteria-kriteria sebagai berikut:

1. Perusahaan indeks LQ45 yang terdaftar di Bursa Efek Indonesia selama tahun 2012-2016

2. Perusahaan indeks LQ45 tersebut menerbitkan laporan keuangan berakhir 31 desember dan sudah diaudit dengan kriteria mendapatkan laba tahun 2012-2016

3. Perusahaan indeks LQ45 tersebut menggunakan mata uang rupiah selama tahun 2012-2016 4. Harga saham diketahui secara jelas.

\subsection{Jenis dan Sumber Data}

\subsubsection{Jenis Data}

Dalam penelitian ini jenis data yang di gunakan yaitu data kuantitatif, yaitu data yang berbentuk angka yang diperoleh dari laporan keuangan yang telah diaudit.

\subsubsection{Sumber Data}

Sumber data yang digunakan dalam penelitian ini adalah data sekunder yang bersumber dari catatan pada perusahaan dan dalam bentuk dokumentasi laporan keuangan yang rutin diterbitkan setiap tahunnya oleh perusahaan dari situs resmi Bursa Efek Indonesia (www.idx.co.id). 


\subsection{Definisi Operasional Variabel}

\subsubsection{Variabel Dependen}

Variabel dependen dalam penelitian ini adalah harga saham. Variabel ini di ukur dengan melihat closing price.

\subsubsection{Variabel Independen \\ variabel independen dalam penelitian ini adalah:}

1. Arus Kas Operasi

Variabel arus kas operasi di ukur dengan.

$$
\text { Arus Kas Operasi }=\frac{\text { Arus Kas Operasi thn } \mathrm{ke}_{1^{-}} \text {thn } \mathrm{ke}_{\mathrm{t}-1}}{\text { Arus Kas Operasi thn } \mathrm{ke}_{\mathrm{t}-1}}
$$

2. Pertumbuhan Penjualan

Pertumbuhan penjualan merupakan perbandingan antara tahun yang bersangkutan (tahun ke 1) dikurangi penjualan tahun sebelumnya (tahun ke t-1) kemudian dibagi dengan penjualan tahun sebelumnya (tahun ke t-1).

$$
\text { Pertumbuhan Penjualan }=\frac{\text { Penjualan thn } k_{1}-\text { thn } \mathrm{ke}_{\mathrm{t}-1}}{\text { Penjualan thn } \mathrm{ke}_{\mathrm{t}-1}}
$$

\subsection{Teknik Pengumpulan Data}

Teknik pengumpulan data dalam penelitian ini menggunakan teknik dokumentasi, yaitu dengan melihat laporan keuangan yang ada di Bursa Efek Indonesia. Dengan mengakses di website Bursa Efek Indonesia (www.idx.co.id). Penelitian ini juga menggunakan studi kepustakaan yaitu dengan cara membaca, mempelajari literature dan publikasi yang berhubungan dengan penelitian.

\subsection{Teknik Analisis Data}

\subsubsection{Uji Asumsi Klasik}

Sebelum melakukan uji regresi dan hipotesis harus dilakukan uji asumsi klasik yaitu uji normalitas, uji multikolinearitas dan uji heteroskedastisitas. Dengan adanya pengujian ini diharapkan agar model regresi yang diperoleh dapat dipertanggungjawabkan.

1. Uji Normalitas, bertujuan untuk menguji apakah data berdistribusi normal atau mendekati normal.

2. Uji Multikoliniearitas, yang bertujuan untuk menguji apakah dalam model regresi ditemukan adanya korelasi antar variabel-variabel bebas.

3. Uji Heteroskedastisitas, menguji apakah model regresi terdapat kesamaan atau tidak terjadi heteroskedastisitas.

\subsubsection{Uji Regresi Linear Berganda}

Model regresi yang digunakan dapat dirumuskan dengan persamaan sebagai berikut:

$$
\mathrm{Y}=\mathrm{a}+\mathrm{b} 1 \mathrm{X} 1+\mathrm{b} 2 \mathrm{X} 2+e
$$

Keterangan:

Y : Harga Saham

$$
\text { e : error }
$$

$\mathrm{X} 1$ : Arus Kas Operasi

$\mathrm{X} 2$ : Pertumbuhan Penjualan

\subsubsection{Koefisien Determinasi $\left(\mathbf{R}^{2}\right)$}

Kemampuan model dalam menerangkan variabel-variabel dependen diukur menggunakan koefisien determinasi $\left(\mathrm{R}^{2}\right)$. Nilai koefisien determinasi adalah antara nol dan satu. 


\subsubsection{Uji Hipotesis}

1. Uji t (Uji Parsial)

Uji t digunakan untuk menguji hipotesis secara parsial dari variabel bebasnya. Pengujian ini dilakukan dengan cara membandingkan t-hitung dengan t-tabel. Jika t-hitung lebih besar dibandingkan dengan t-tabel pada taraf signifikansi $(\alpha) 5 \%$, maka variabel pengaruh memiliki pengaruh yang signifikan.

2. Uji f (Uji Simultan)

Uji t digunakan untuk menguji hipotesis secara simultan. Pengujian ini dilakukan dengan cara membandingkan f-hitung dengan f-tabel. Jika f-hitung lebih besar dibandingkan dengan f-tabel pada taraf signifikansi $(\alpha) 5 \%$, maka variabel pengaruh memiliki pengaruh yang signifikan.

\section{HASIL ANALISIS DAN PEMBAHASAN}

\subsection{Hasil analisis}

\subsubsection{Uji Asumsi Klasik}

Uji Normalitas

Dari Hasil uji normalitas diperoleh hasil sebagai berikut.

Tabel 4.2 Uji Normalitas Kolmogorov - Smirnov One-Sample Kolmogorov-Smirnov Test

\begin{tabular}{|c|c|c|}
\hline & & Unstandardized Residual \\
\hline $\begin{array}{l}\text { N } \\
\text { Normal Parameters }{ }^{\mathrm{a}, \mathrm{b}} \\
\text { Most Extreme Differences } \\
\text { Kolmogorov-Smirnov Z } \\
\text { Asymp. Sig. (2-tailed) }\end{array}$ & $\begin{array}{l}\text { Mean } \\
\text { Std. Deviation } \\
\text { Absolute } \\
\text { Positive } \\
\text { Negative }\end{array}$ & $\begin{array}{r}30 \\
0 \mathrm{E}-7 \\
24190.41736854 \\
.150 \\
.150 \\
-.085 \\
.821 \\
.510\end{array}$ \\
\hline
\end{tabular}

a. Test distribution is Normal.

b. Calculated from data.

(Sumber : Hasil Pegolahan Data Aplikasi SPSS, 2018)

Hasil uji normalitas diperoleh nilai signifikansi sebesar 0,510 (Asymp. Sig. (2-tailed)) dimana $0,510>0,05$ maka dapat disimpulkan data berdistribusi normal.

Uji Multikolinearitas

Dari hasil uji multikolinearias diperoleh hasil untuk masing-masing variabel sebagai berikut.

Tabel 4.3 Uji Multikolinearitas

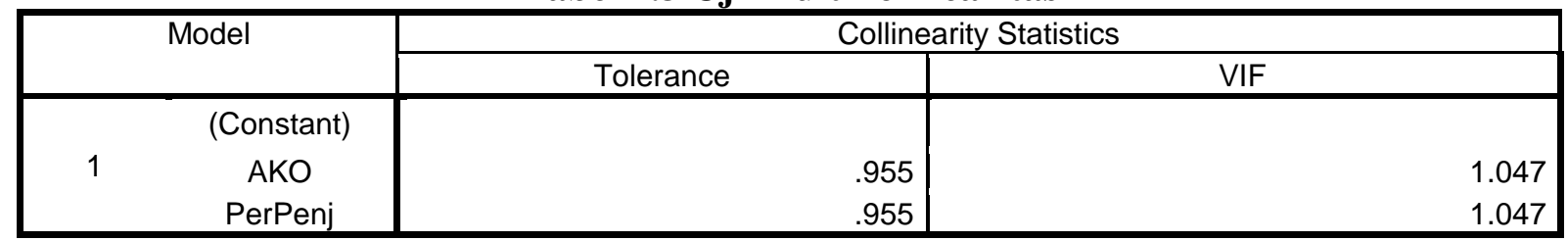

(Sumber : Hasil Pegolahan Data Aplikasi SPSS, 2018)

Berdasarkan hasil uji multikolinearitas diperoleh Arus Kas Operasi nilai tolerance 0,955 > 0,1 dan nilai VIF $1,047<10$, Pertumbuhan Penjualan nilai tolerance 0,955 > 0,1 dan nilai VIF $1,047<10$. Jadi dapat disimpukan bahwa tidak ada multikolinearitas antara variabel independen dalam model regresi karena semua variabel independen memiliki nilai tolerance $>0,1$ dan nilai $\mathrm{VIF}<10$. 
Uji Heteroskedastisitas

Dari hasil uji heteroskedastisitas diperoleh hasil sebagai berikut.

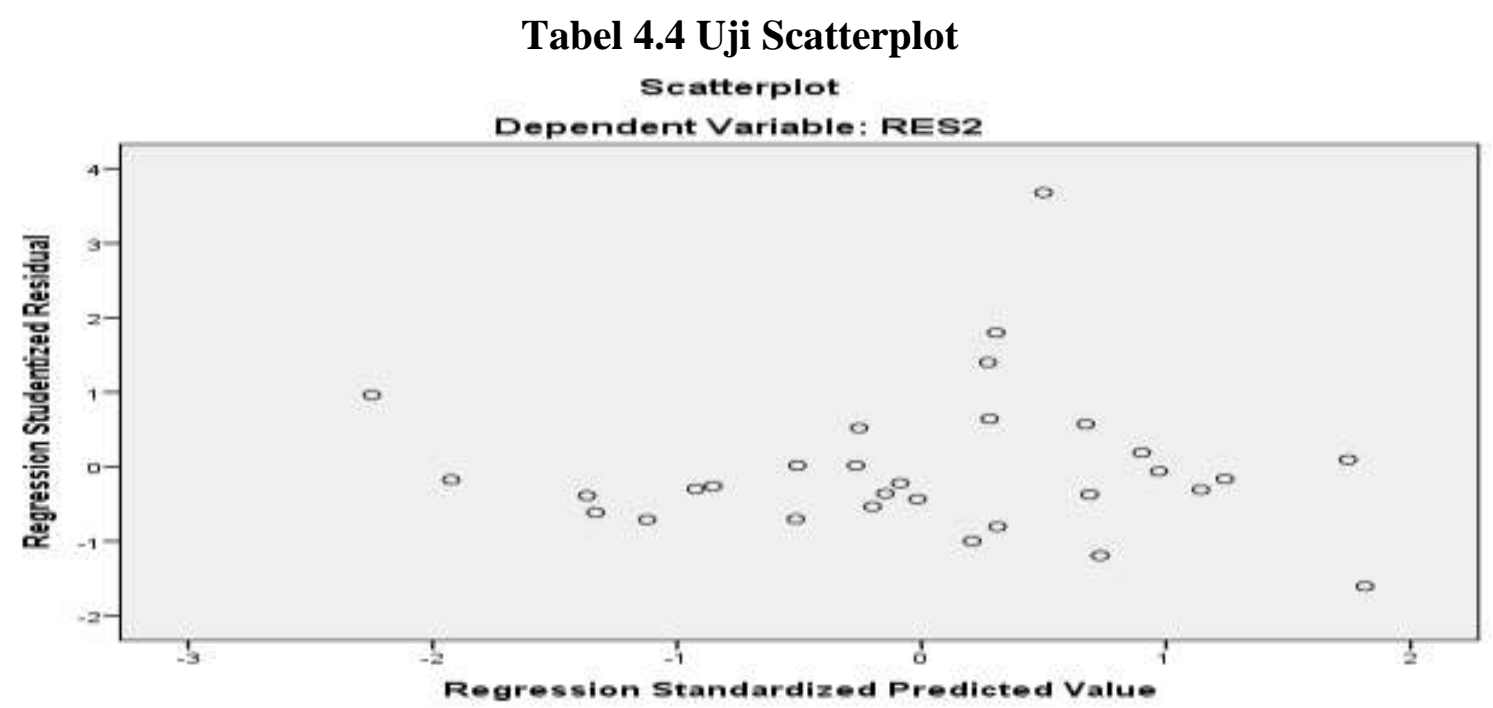

(Sumber : Hasil Pegolahan Data Aplikasi SPSS, 2018)

Berdasarkan output scatterplot di atas, terlihat bahwa titik-titik menyebar secara acak dan tidak membentuksebuah pola tertentu yang jelas (menyempit). Hal ini berarti tidak terjadi heterokedastisitas pada model regresi, sehingga model regresi layak di pakai untuk analisis berikutnya.

\subsubsection{Uji Regresi Linear Berganda}

Hasil uji regresi linear berganda diperoleh hasil sebagai berikut.

Tabel 4.5 Uji Regresi Linear Berganda Coefficients $^{a}$

\begin{tabular}{|c|c|c|c|c|c|c|}
\hline & \multirow[t]{2}{*}{ Model } & \multicolumn{2}{|c|}{ Unstandardized Coefficients } & \multirow{2}{*}{$\begin{array}{c}\begin{array}{c}\text { Standardized } \\
\text { Coefficients }\end{array} \\
\text { Beta }\end{array}$} & \multirow[t]{2}{*}{ T } & \multirow[t]{2}{*}{ Sig. } \\
\hline & & $B$ & Std. Error & & & \\
\hline \multirow{3}{*}{1} & (Constant) & 17534.285 & 5064.749 & & 3.462 & .002 \\
\hline & AKO & 145.379 & 566.296 & .045 & .257 & .799 \\
\hline & PerPenj & 102250.514 & 38531.619 & .461 & 2.654 & .013 \\
\hline
\end{tabular}

a. Dependent Variable: Hsaham

(Sumber : Hasil Pegolahan Data Aplikasi SPSS, 2018)

Dari Tabel 4.6 dapat diperoleh persamaan regresi linier berganda sebagai berikut.

$\mathrm{Y}=17534,285+145,379 \mathrm{X} 1+102250,514 \mathrm{X} 2+\mathrm{e}$

Keterangan:

Y : Harga Saham

$\mathrm{X} 1$ : Arus Kas Operasi

$\mathrm{X} 2$ : Pertumbuhan Penjualan

e : Standart error

\subsubsection{Koefisien Determinasi $\left(R^{2}\right)$}

Dari hasil uji regresi linear berganda diperoleh hasil sebagai berikut : 


\section{Tabel 4.6 Koefisien Determinasi}

Model Summary

\begin{tabular}{|c|r|r|r|r|}
\hline Model & R & R Square & Adjusted R Square & Std. Error of the Estimate \\
\hline 1 & $.472^{\mathrm{a}}$ & .223 & .165 & 25070.35469 \\
\hline
\end{tabular}

a. Predictors: (Constant), PerPenj, AKO

(Sumber : Hasil Pegolahan DataAplikasi SPSS, 2018)

Dari hasil pengolahan data dengan metode regresi linear berganda, diperoleh hasil koefisien determinasi berdasarkan nilai adjusted yaitu sebesar 0,165. Jadi kemampuan variabel independen yaitu arus kas operasi dan pertumbuhan penjualan dari variabel dependen yaitu harga saham sebesar $16,5 \%$ sedangkan sisanya sebesar $83,5 \%$ dijelaskan oleh faktor-faktor lain yang tidak diikut sertakan dalam penelitian ini.

\subsubsection{Uji Hipotesis}

Uji t (Uji Parsial)

Dari hasil uji regresi linear berganda diperoleh hasil sebagai berikut.

\begin{tabular}{|c|c|c|c|c|c|c|}
\hline \multicolumn{7}{|c|}{$\begin{array}{c}\text { Tabel 4.7 Uji t } \\
\text { Coefficients }^{\mathrm{a}}\end{array}$} \\
\hline \multirow{2}{*}{\multicolumn{2}{|c|}{ Model }} & \multicolumn{2}{|c|}{ Unstandardized Coefficients } & \multirow{2}{*}{$\begin{array}{c}\text { Standardized } \\
\text { Coefficients } \\
\text { Beta }\end{array}$} & \multirow[t]{2}{*}{$\mathrm{t}$} & \multirow[t]{2}{*}{ Sig. } \\
\hline & & $\mathrm{B}$ & Std. Error & & & \\
\hline \multirow{3}{*}{1} & (Constant) & 17534.285 & 5064.749 & & 3.462 & .002 \\
\hline & AKO & 145.379 & 566.296 & .045 & .257 & .799 \\
\hline & PerPenj & 102250.514 & 38531.619 & .461 & 2.654 & .013 \\
\hline
\end{tabular}

a. Dependent Variable: Hsaham

(Sumber : Hasil Pegolahan Data Aplikasi SPSS, 2018)

Berdasarkan hasil analisis regresi secara parsial, maka diperoleh arus kas operasi memiliki nilai t-hitung sebesar $0,257<2,048$ dan nilai signifikansi $0,799>0,05$, pertumbuhan penjualan memiliki nilai t-hitung sebesar 2,654>2,048 dan nilai signifikansi $0,013<0,05$. Jadi dapat disimpulkan bahwa arus kas operasi tidak berpengaruh signifikan terhadap harga saham maka $\mathrm{H} 1$ ditolak dan $\mathrm{H} 0$ diterima karena t-hitung $<\mathrm{t}$-tabel dan tingkat signifikansi $>0,05$, dan pertumbuhan penjualan berpengaruh signifikan terhadap harga saham maka $\mathrm{H} 2$ diterima dan H0 ditolak karena t-hitung $>$ t-tabel dan tingkat signifikansi $<0,05$.

Uji F (Simultan)

Dari hasil uji regresi linear berganda diperoleh hasil sebagai berikut :

Tabel 4.8 Uji F

ANOVA $^{\mathrm{a}}$

\begin{tabular}{|ll|r|r|r|r|r|}
\hline \multicolumn{1}{|c|}{ Model } & \multicolumn{1}{|c|}{ Sum of Squares } & \multicolumn{1}{|c|}{ Df } & \multicolumn{1}{|c|}{ Mean Square } & F & \multicolumn{1}{c|}{ Sig. } \\
\hline \multirow{4}{*}{1} & Regression & 4870259192.707 & 2 & 2435129596.354 & 3.874 & $.033^{\text {b }}$ \\
& Residual & 16970112481.459 & 27 & 628522684.498 & & \\
& Total & 21840371674.167 & 29 & & & \\
\hline
\end{tabular}

a. Dependent Variable: Hsaham

b. Predictors: (Constant), PerPenj, AKO

(Sumber : Hasil Pegolahan Data Aplikasi SPSS, 2018)

Berdasarkan hasil analisis regresi uji f, maka diperoleh nilai F-hitung sebesar 3,874> 3,320 dan nilai signifikansi $0,033<0,05$. Jadi dapat disimpulkan bahwa arus kas operasi dan pertumbuhan penjualan berpengaruh signifikan terhadap harga saham karena F-hitung $>$ Ftabel dan tingkat signifikansi $<0,05$. 


\subsubsection{Pembahasan}

a. Pengaruh Arus Kas Operasi terhadap Harga Saham

Berdasarkan hasil pengujian yang dilakukan diketahui bahwa arus kas operasi memiliki nilai $t_{\text {hitung }} 0,257<2,048$ dan nilai signifikansi 0,799>0,05 dengan demikian maka bedasarkan hipotesis penelitian $\mathrm{H} 1$ ditolak dan $\mathrm{H} 0$ diterima. Artinya dapat disimpulkan bahwa secara parsial variabel independen yakni Arus Kas Operasi tidak berpengaruh signifikan terhadap variabel dependen yakni harga saham. Arus Kas Operasi mempunyai hubungan searah terhadap harga saham, dimana semakin besar arus kas operasi maka harga saham semakin bertambah. Hasil penelitian ini dikhususkan pada objek penelitian perusahaan indeks LQ45 yang terdaftar di Bursa Efek Indonesia periode 2012 sampai dengan 2016.

b. Pengaruh Pertumbuhan Penjualan terhadap Harga Saham

Berdasarkan hasil pengujian yang dilakukan diketahui bahwa pertumbuhan penjualan memiliki nilai $t_{\text {hitung }} 2,654>2,048$ dan nilai signifikansi $0,013<0,05$ dengan demikian maka bedasarkan hipotesis penelitian $\mathrm{H} 1$ diterima dan H0 ditolak. Artinya dapat disimpulkan bahwa secara parsial variabel independen yakni Pertumbuhan Penjualan berpengaruh signifikan terhadap variabel dependen yakni harga saham. Pertumbuhan Penjualan mempunyai hubungan searah terhadap harga saham, dimana semakin besar pertumbuhan penjualan maka harga saham semakin bertambah. Hasil penelitian ini dikhususkan pada objek penelitian perusahaan indeks LQ45 yang terdaftar di Bursa Efek Indonesia periode 2012 sampai dengan 2016.

\section{KESIMPULAN DAN SARAN \\ 5.1 Kesimpulan}

Berdasarkan hasil penelitian yang telah dikemukakan di atas, maka dapat ditarik kesimpulan sebagai berikut:

1. Arus Kas Operasi berpengaruh positif dan tidak signifikan terhadap harga saham, terbukti dengan hasil uji hipotesis parsial (uji t) yang telah di lakukan. Dengan demikian, hipotesis pertama (H1) ditolak.

2. Pertumbuhan penjualan berpengaruh positif dan signifikan terhadap harga saham, terbukti dengan hasil uji hipotesis parsial (uji t) yang telah di lakukan. Dengan demikian, hipotesis kedua (H2) diterima.

\subsubsection{Saran}

Berdasarkan hasil penelitian yang telah dikemukakan di atas, maka penulis memberikan saran yang mungkin dapat digunakan sebagai dasar pertimbangan bagi perusahaan dan pihak-pihak lain yang berkepentingan, dan saran yang diberikan yaitu sebagai berikut:

1. Bagi perusahaan, dapat lebih memperhatikan faktor-faktor fundamental yang dapat digunakan investor dalam memprediksi harga saham. Perusahaan dapat lebih meningkatkan kinerja perusahaan yang ada.

2. Bagi investor, yang bermaksud melakukan investasi sahamnya pada suatu perusahaan sebaiknya melihat terlebih dahulu kondisi perusahaan yang akan dipilih. Dan memperhatikan faktor fundamental dari saham yang dimiliki, atau hendak dimiliki. Dalam hal ini investor harus menempatkan saham yang akan ditanamkannya pada perusahaan yang tepat.

3. Bagi Peneliti Selanjutnya, diharapkan dapat meneliti faktor-faktor fundamental lainnya terhadap harga saham. Penelitian selanjutnya juga dapat melakukan penelitian harga saham pada sektor maupun sub sektor lainnya, mengingat setiap sektor maupun sub sektor mempunyai karakteristik yang berbeda-beda. 


\section{DAFTAR PUSTAKA}

Astuti, D. Kurnia. 2016. Pengaruh Net Profit (NPM) dan Pertumbuhan Penjualan terhadap Harga Saham (Survei pada Perusahaan Manufaktur Sektor Industri Barang Konsumsi yang terdaftar di Bursa Efek Indonesia Tahun 2012-2015. Skripsi. Universitas Komputer Indonesia. Bandung.

Bodie, Zvi., Kane., Alex., and Marcus, Alan J. 2014. Investments and Portofolio. Diterjemahkan oleh Zulaini Dalimunthe dan Egi ferdianto analisi pengaruh return on asset (roa), debt to equity ratio (der), net profit margin (npm) dan current ratio (cr) terhadap harga saham.

Fahmi, Irham. 2012. Manajemen Investasi. Bandung: Alfabeta.

Hery, 2017. Kajian Riset Akuntansi, Jakarta: Penerbit PT Grasindo

Ikatan Akuntan Indonesia. 2015. Standar Akuntansi Keuangan. Jakarta: Ikatan Akuntan Indonesia

Kieso., Donald E., Jerry J. Weygant, dan Terry D. Warfield. 2011. Intermediate Accounting, (Jilid 1) Edisi ke-12. Diterjemahkan oleh Emil Salim. Jakarta: Erlangga.

Lisan, Faris. 2011. Pengaruh Arus Kas Operasi Terhadap Harga Saham dengan Persistensi Laba Sebagai Variabel Intervening.Skripsi. Sekolah Tinggi Ilmu Ekonomi Perbanas. Surabaya.

Rini. P. Erlin. 2016. Pengaruh Arus Kas, Kebijakan Dividen, Dan Pertumbuhan Penjualan Terhadap Harga Saham Pada Perusahaan Manufaktur Yang Terdaftar di Bursa Efek Indonesia tahun 2010-2014. Skripsi.Universitas Muhamadiyah Surakarta. Jawa Tengah.

Subramanyam. K. R, dan John J. Wild. 2014. Analisis Laporan Keuangan. Penerjemah Dewi Y. Jakarta: Salemba Empat.

Widarjo, Wahyu, dan Setiawan, Doddy. 2009. Pengaruh Rasio Keuangan terhadap Kondisi Financial Distress Perusahaan Otomotif.Jurnal Bisnis dan Akuntansi. Vol. 11, No. 2, Agustus 2009, Hlm. 107-119.

Sugiyono. 2013. Metode Penelitian Kuantitatif, Kualitatif dan R\&D. Bandung: Alfabeta.CV 